\title{
White Lupin as a Promising Source of Antioxidant Phenolics for Functional Food Production
}

\author{
Alena Vollmannova $\left(\mathbb{D},{ }^{1}\right.$ Judita Lidikova $\left(\mathbb{D},{ }^{1}\right.$ Janette Musilova $\left(\mathbb{D},{ }^{1}\right.$ Marek Snirc $\left(\mathbb{D},{ }^{1}\right.$ \\ Tatiana Bojnanska $\mathbb{D}^{\mathrm{D}},{ }^{2}$ Dana Urminska $\mathbb{D}^{\mathrm{D}},{ }^{3}$ Ivana Tirdilova $\mathbb{D}^{1},{ }^{1}$ and Erika Zetochova ${ }^{4}{ }^{4}$ \\ ${ }^{1}$ Department of Chemistry, Faculty of Biotechnology and Food Sciences, Slovak University of Agriculture in Nitra, \\ Nitra 94976, Slovakia \\ ${ }^{2}$ Department of Technology and Quality of Plant Products, Faculty of Biotechnology and Food Sciences, \\ Slovak University of Agriculture in Nitra, Nitra 94976, Slovakia \\ ${ }^{3}$ Department of Biochemistry and Biotechnology, Faculty of Biotechnology and Food Sciences, \\ Slovak University of Agriculture in Nitra, Nitra 94976, Slovakia \\ ${ }^{4}$ Research Institute of Plant Production in Piestany, National Agricultural and Food Centre, Piestany 92168, Slovakia \\ Correspondence should be addressed to Alena Vollmannova; alena.vollmannova@uniag.sk
}

Received 15 January 2021; Revised 11 June 2021; Accepted 15 June 2021; Published 29 June 2021

Academic Editor: Antonio J. Signes-Pastor

Copyright (c) 2021 Alena Vollmannova et al. This is an open access article distributed under the Creative Commons Attribution License, which permits unrestricted use, distribution, and reproduction in any medium, provided the original work is properly cited.

\begin{abstract}
Although white lupin is the oldest known legume in the history, it has been forgotten for many years. Now, the interest of food producers concerning white lupin is increased again. The aim of this study was to evaluate the total phenolic content (TPC), antioxidant activity (AA), and the content of selected phenolics in 11 white lupin cultivars. The determined TPC was in the interval 4260-5663 mg GAE $/ \mathrm{kg} \mathrm{DM}$ and the values of AA determined using DPPH ${ }^{\bullet}, \mathrm{ABTS}^{\bullet+}$, and FRAP methods were in the ranges $0.993-1.878,5.496-7.924$, and 1.328-1.741 $\mu \mathrm{mol}$ TE/g DM, respectively. Individual phenolics content (4-hydroxybenzoic acid, caffeic acid, trans- $p$-coumaric acid, trans-ferulic acid, myricetin, quercetin, apigenin, and genistein) were determined, too. Caffeic acid (442.9-766.2 mg/kg DM) and myricetin (11.2-21.2 mg/kg DM) are the dominant phenolics in the investigated lupin cultivars. Statistically significant differences in all investigated variables were observed between the tested cultivars except for quercetin. The obtained results show that the Astra and Nelly cultivars are a rich source of phenolic acids.
\end{abstract}

\section{Introduction}

Legumes play an important role in human nutrition and are the part of the traditional diets of many regions throughout the world. They are mainly grown for their edible seeds and they occupy large cropped areas worldwide. Legumes have a low content of fat but, on the other hand, a remarkable content of protein, fibre, micronutrients, and many valuable phytochemicals [1]. Legumes as a part of daily diet can exhibit beneficial physiological effects and thus can help in control and prevention against diseases of civilization such as diabetes mellitus, coronary heart disease, and colon cancer [2]. A long-standing problem connecting with legumes has been the high content of antinutritional factors that could limit their biological value. According to the current research, these compounds can be easily removed or reduced by the change of processing conditions; some of these substances could show also positive effects on the human health [3]. Due to known positive effect of legume consumption, their production is increased worldwide. In Europe, the higher consumption of legumes $(8-23 \mathrm{~g}$ per capita daily) is reported in Mediterranean countries. In countries of Northern Europe, it is less than $5 \mathrm{~g}$ [4].

White lupin is favored for better nitrogen fixation, drought adaptation and generally could offer considerable human food in marginal lands with limited water availability [5]. Due to the ability of lupin to fix nitrogen, it can be used not only for improvement of soil fertility, but also for 
rehabilitation of degraded lands. Intercropping white and Andean lupins with other cool-season annual legumes may lead to higher forage and grain yields, and it provides farmers with high-quality forage and grain richer in protein [6]. White lupin as a cool-season and environmentally friendly protein crop does not need $\mathrm{N}$-fertilization, has benefits for subsequent crops, and prefers free-draining soils with low lime content (below 3\%). The lime in the fine clay and silt fractions prevents lupin from absorbing iron from the soil, which the nodules need for nitrogen fixation [7]. Precipitation during the critical period of vegetation belongs to the most important factors affecting the yields of this crop [8]. Lupins are relatively more tolerant to several abiotic stresses than other legumes and have a proven potential for the recovery of poor and contaminated soils. It could be used as a pioneer plant to fight soil erosion and to reclaim eroded soils or as a potential phytoremediator due to the capability to accumulate $\mathrm{Cd}, \mathrm{Zn}$, and other heavy metals in the nodulated roots [9].

More than 3000 years' seeds of white lupin have been used not only as food component but also for the therapeutic purposes, even though due to the high alkaloid content, its consumption as a food component was not considered as safe [10]. The interest of researchers in recent years is focused especially on the breeding and production of lupin cultivars with a high-protein content, low alkaloid content, and short vegetation period [11]. Among legume seeds, lupin is one of the richest abundant sources of proteins [12]. The seeds of white lupin contain 33 to $47 \%$ protein, $16.2 \%$ fibre, $5.95 \%$ oil, $5.82 \%$ sugar, and, unlike cereals, a low content of starch (5-12\%) [13]. Erbaş et al. [13] also reported that lupin seeds are rich in thiamin $(3.9 \mathrm{mg} / \mathrm{kg})$, riboflavin $(2.3 \mathrm{mg} / \mathrm{kg})$, and niacin $(39 \mathrm{mg} / \mathrm{kg})$, too. According to [14], seeds of white lupin have a low content of sodium $(0.17 \mathrm{~g} / \mathrm{kg})$; on the other hand, they are a good source of macroelements $\mathrm{K}, \mathrm{P}, \mathrm{Ca}$, and $\mathrm{Mg}(11.0,5.2,2.4$, and $1.3 \mathrm{~g} / \mathrm{kg}$, respectively) and microelements $\mathrm{Mn}, \mathrm{Fe}, \mathrm{Zn}$, and $\mathrm{Cu}(252,39,43$, and $8 \mathrm{mg} / \mathrm{kg}$, respectively). Sebastiá et al. [15] compared $\mathrm{Ca}, \mathrm{Fe}$, and $\mathrm{Zn}$ contents in three legumes (beans, chickpeas, and lentils) and determined lower $\mathrm{Ca}(0,77-1.54 \mathrm{~g} / \mathrm{kg})$ as well as $\mathrm{Zn}$ $(33.71-36.89 \mathrm{mg} / \mathrm{kg}$ ) contents compared to mentioned values determined in white lupin. Seeds of white lupin have an interesting content of biologically valuable substances with a high antioxidant potential, such as tannins and flavonoids [16]. The most important nutritional benefit of white lupin is the highest oil content and a lower content of alkaloids compared to blue or yellow lupin [11]. Foods with lupin addition can not only contribute to rational nutrition and a feeling of satiety of consumers but also help in the prevention of diseases, in lipid metabolism improvement, and in blood pressure treatment [17]. Lupin ingredients, such as lupin flour and protein concentrates, are used as minor components in bakery products (bread, bisquits, pasta, cakes, breakfast cereals, or pancakes). These glutenfree food products are suitable also for the people with celiac disease $[18,19]$. The development of novel lupin-based foods should probably focus first on replacement of animal products (meat alternative, vegetarian spreads, dessert creams, ice-cream, and vegetable drinks). Further targets include high-protein food products with excellent sensory properties (sausages, snacks, and drinks) [20]. White lupin seeds have not been widely utilized in the human nutrition due to their alkaloid content. However, it should be noted that the domestication of this legume as well as its breeding resulted in a decrease of the alkaloid content in breeding lines and cultivars classes [21], and thus this crop becomes an interesting food raw material. Functional food science has gained a great interest in the last years due to the changing health status of population in developed countries. The main aims of the population are to be healthy and to have a high life quality [22]. Several preclinical studies demonstrated that seeds of Lupinus albus L. have antimicrobial, antioxidant, antihelmintic, hypolipidemic, hypoglycemic, anticonvulsant, and antiatherosclerotic activities [23-25]. Many components of white lupin seeds are very valuable raw materials for functional food production. Lupin protein has a potential to be an inflammatory agent with the positive effect on metabolism, nutrient absorption, and imunity [26]. Pavanello et al. [27] reported the reduction of total cholesterol concentration caused by intake of a lupin protein concentrate. Protein hydrolysates with a remarkable content of bioactive peptides are suitable for the design of functional foods and nutraceuticals. Also, the large amount of dietary fibre has a potential to be utilised in functional foods production [28]. Mazumder et al. [28] investigated trichloroacetic acid extracts of seed coat and found the induction of apoptosis in human pancreas carcinoma. The content of quinolizidine alkaloids was at levels below human toxicity but with potential health benefits of diabetic patients. Authors consider lupin as a potentially nutraceutical and functional food.

The aim of this study was to compare the total phenolic content (TPC), antioxidant activity (AA), and the content of selected phenolic compounds in 11 white lupin cultivars from 9 different countries of origin which were grown at the same locality in the same conditions and to investigate the effect of the cultivar on monitored parameters.

\section{Materials and Methods}

2.1. Plant Material and Chemicals. Samples of 11 white lupin cultivars were obtained from the Plant Production Research Center in Piestany, Slovakia. Lupin cultivars were grown at the same location, in the same agronomic, environmental, and climate conditions. Latitude and longitude for experimental field were $48^{\circ} 35^{\prime} 08^{\prime \prime} \mathrm{N} ; 17^{\circ} 48^{\prime} 56^{\prime \prime} \mathrm{E}$. The countries of cultivars origin are as follows: France (cv. Alban), Chile (cv. Astra), Poland (cvs. R-933, POP I, and WTD), Romania (cv. Satmarean), Hungary (cv. Nelly), Spain (cv. Los Palacios), Russia (cv. Primorskij), Slovenia (cv. Solnecnyj), and Germany (cv. Weibit). Determination of lupin seed dry matter was performed by drying at $105^{\circ} \mathrm{C}$ to constant weight (WTC Binder, Germany) and then lupin seeds were powdered (Fritsch Pulverisette, Germany).

Folin-Ciocalteau reagent used for determination of total phenolic content was purchased from Merck (Germany). All other chemicals (methanol, 2, 2-diphenyl-1-picrylhydrazyl, $\mathrm{Na}_{2} \mathrm{CO}_{3}$, gallic acid, Trolox, ABTS ${ }^{\circ+}$, acetate buffer, TPTZ, 
and $\mathrm{FeCl}_{3} \cdot 6 \mathrm{H}_{2} \mathrm{O}$ ) including all HPLC standards (purity range 98.0-99.9\%), that is, 4-hydroxybenzoic acid, caffeic acid, trans-p-coumaric acid, trans-ferulic acid, myricetin, quercetin, apigenin, genistein, and solvents; methanol (HPLC grade), acetonitrile (gradient HPLC grade), and phosphoric acid (ACS grade) were purchased from SigmaAldrich (Sigma Aldrich Chemie GmbH, Steiheim, Germany). Double deionized water $\left(\mathrm{ddH}_{2} \mathrm{O}\right)$ was treated $\left(18.2 \mathrm{M} \Omega / \mathrm{cm}, 20^{\circ} \mathrm{C}\right)$ in a Simplicity 185 purification system (Millipore SAS, Molsheim, France).

2.2. Extract Preparation. Plant extracts were prepared according to the modified procedure of Rajurkar and Hande [29]. The homogenized lupin samples $(2 \mathrm{~g})$ were extracted with $20 \mathrm{~mL} 80 \%$ methanol (v/v) (Sigma-Aldrich, USA) at laboratory temperature for 8 hours by horizontal shaker Unimax 2010 (Heidolph Instruments, GmbH, Germany). The extract was filtered through Munktell No. 390 paper (Munktell and Filtrak GmbH, Bärenstein, Germany) and stored in closed $20 \mathrm{~mL}$ PE vial tubes.

2.3. Determination of Total Phenolic Content. For the total phenolic content determination, Folin-Ciocalteau reagent (Merck, Germany) according to the protocol of Lachman et al. [30] was used. Sample extract $(0.2 \mathrm{~mL}), 2.5 \mathrm{~mL}$ Folin-Ciocalteau reagent, and $5 \mathrm{~mL} \mathrm{H}_{2} \mathrm{O}$ were added to a $50 \mathrm{~mL}$ flask. After $3 \mathrm{~min}, 5 \mathrm{~mL}$ of $20 \% \mathrm{Na}_{2} \mathrm{CO}_{3}$ (SigmaAldrich, USA) was added to the flask, and the volume was then made up to $50 \mathrm{~mL}$ with distilled water and left to stay at room temperature for $2 \mathrm{~h}$. When a coloured blue complex was formed, the absorbance was measured at $765 \mathrm{~nm}$ on the spectrophotometer Shimadzu UV-VIS 1800 (Shimadzu, Japan). The total phenolic content was expressed as gallic acid equivalents (GAE) in $\mathrm{mg} / \mathrm{kg}$ DM (dry matter). The linearity range for this assay was determined at $0-150 \mu \mathrm{g} / \mathrm{mL}$ $\left(R^{2}=0.9948\right)$.

2.4. DPPH Free Radical Scavenging Assay. The assessment of free radical scavenging activity using 2,2-diphenyl-1-picrylhydrazyl radical $\left(\mathrm{DPPH}^{\circ}\right)$ was performed according to the protocol in Brand-Williams et al. [31]. The stock solution was prepared using $0.025 \mathrm{~g}$ of $\mathrm{DPPH}^{\circ}$, which was diluted to $100 \mathrm{~mL}$ with methanol. Before the analysis, the working solution by a $1: 10$ dilution of the stock with methanol was obtained. For the analysis, $3.9 \mathrm{~mL}$ of the $\mathrm{DPPH}^{\bullet}$ working solution was added to a cuvette, and the absorbance at $516 \mathrm{~nm}$ was measured $\left(A_{0}\right)$ with a Shimadzu UV-Vis 1800 spectrophotometer (Shimadzu, Japan). Subsequently, $0.1 \mathrm{~mL}$ of the extract was added to the cuvette with $\mathrm{DPPH}^{\bullet}$ solution, and the absorbance was measured after $10 \min \left(A_{10}\right)$.

The percentage of DPPH inhibition was measured according to the following equation:

Inhibition $(\%)=\left[\left(A_{0}-A_{10}\right) / A_{0}\right] \times 100$.

Free radical scavenging activity was expressed in $\mu \mathrm{mol}$ Trolox equivalent (TE)/g DM on the basis of the standard curve $\left(R^{2}=0.9905\right)$.
ABTS $\bullet+$ scavenging ability assay is based on the scavenge a stabile synthetic 2,2'-azino-bis(3-ethylbenzthiazoline- 6-sulfonic) acid (ABTS ${ }^{++}$radical cation). Due to the antioxidant presence, the significantly blue/green colored radical is reduced and decolored. The analysis was done according to protocol in Re et al. [32].

ABTS $^{\bullet+}$ (Sigma-Aldrich, USA) was dissolved in water to a $7 \mathrm{mM}$ concentration. The blue/green $\mathrm{ABTS}^{\bullet+}$ radical cation was produced through the reaction between $\mathrm{ABTS}^{\bullet+}$ stock solution and $2.45 \mathrm{mM}$ potassium persulfate. After the addition of $50 \mu \mathrm{L}$ of lupine extract to $3 \mathrm{~mL}$ of diluted $\mathrm{ABTS}^{\bullet+}$ solution, the absorbance was measured at $20 \mathrm{~min}$ after the initial mixing using Shimadzu UV-1800 spectrophotometer set at $734 \mathrm{~nm}$ wavelength. Trolox was used as a standard substance. An appropriate solvent blank was run in each assay. Based on calibration curve $\left(R^{2}=0.9573\right)$, the results were expressed as $\mu \mathrm{mol}$ Trolox equivalent (TE)/g DM.

\subsection{Ferric-Reducing Antioxidant Power (FRAP) Assay.} The method is based on the reduction of $\mathrm{Fe}^{3+}-(2,4,6$-tris (2pyridyl)-S-triazine) (TPTZ) complex (colorless complex) to $\mathrm{Fe}^{2+}$-TPTZ complex (blue-colored complex) formed by the action of electron donating antioxidants at low $\mathrm{pH}$. For the antioxidant activity determination, the modified protocol presented by Pedersen et al. [33] was used.

The FRAP reagent was prepared by mixing acetate buffer, TPTZ and $\mathrm{FeCl}_{3} \cdot 6 \mathrm{H}_{2} \mathrm{O}$ (Sigma-Aldrich, USA). $50 \mu \mathrm{L}$ of lupine extract was added to $3.0 \mathrm{~mL}$ of the FRAP reagent to tubes, and the mixture was then left at rest for $20 \mathrm{~min}$. The absorbance of the samples was measured in comparison to a blank at a wavelength of $593 \mathrm{~nm}$ using the Shimadzu UV1800 spectrophotometer. The calibration curve was prepared using standard solutions of Trolox. The results were expressed as $\mu \mathrm{mol}$ Trolox equivalent (TE)/g DM on the basis of the standard curve $\left(R^{2}=0.9989\right)$.

2.6. Determination of Selected Phenolics Content. The individual phenolics were determined using HPLC with diode array detector (HPLC-DAD). Prior to HPLC analysis, the extract was filtered through syringe filter Q-Max $(0.22 \mu \mathrm{m}$, $25 \mathrm{~mm}$, PVDF) (Frisenette ApS, Knebel, Denmark) [34]. All compounds were determined using an Agilent 1260 Infinity HPLC (Agilent Technologie GmbH, Wäldbronn, Germany) with quaternary solvent manager coupled with degasser (G1311B), sampler manager (G1329B), column manager (G1316A), and DAD (G1315C). All HPLC analyses were performed on a Purosphere reverse phase C18 column $(250 \mathrm{~mm} \times 4 \mathrm{~mm} \times 5 \mu \mathrm{m})$ (Merck KGaA, Darmstadt, Germany). The mobile phase consisted of gradient acetonitrile (A) and $0.1 \%$ phosphoric acid in $\mathrm{ddH}_{2} \mathrm{O}$ (B). The gradient elution was as follows: $0-1 \mathrm{~min}$ isocratic elution $(20 \%$ of $\mathrm{A})$, $1-5$ min linear gradient elution $(20-25 \%$ of A), $5-15 \mathrm{~min}$ (25-30\% of A), and $15-25 \mathrm{~min}(30-40 \%$ of A). The postrun was $3 \mathrm{~min}$. The flow rate was $1 \mathrm{~mL} / \mathrm{min}$ and the injection volume was $5 \mu \mathrm{L}$. Column thermostat was set up to $30^{\circ} \mathrm{C}$, and the samples were kept at $4^{\circ} \mathrm{C}$ in the sampler manager [35]. The spectral characteristics of the monitored analytes were scanned in the wavelength range $210-400 \mathrm{~nm}$, while 
detection wavelengths were set up at $265 \mathrm{~nm}$ (4-hydroxybenzoic acid), $320 \mathrm{~nm}$ (caffeic acid, trans-p-coumaric acid, and trans-ferulic acid), and $372 \mathrm{~nm}$ (myricetin, quercetin, apigenin, and genistein). Compounds were identified and quantified by comparing the retention times of standard substances and comparing the run of the spectral UV lines of the analytes. Data were collected and processed using Agilent Open Lab Chem Station software for LC 3D systems.

2.7. Statistical Analysis. Each chemical analysis was done four times. All the data obtained were analyzed by descriptive statistics arithmetic average and standard deviation. Then, all the variables were tested for normality. In all cases with the exception of FRAP variable, the tested variables follow the Gaussian distribution according to the Kolmogorov-Smirnov test and the Shapiro-Wilk test. The Pearson correlation test at the significance level $\alpha=0.05$ was used to analyse the relationships between the elements. No significant differences were evaluated from the correlation matrixes. The multivariate statistical technique (PCA) was used to find the pattern of similarity of the observations and the variables by displaying them as points in the map. Analysis of variance was performed to find the significant differences between the variables tested. In the case of FRAP variable, Kruskal-Wallis test was performed. For a better understanding and interpretation of the results, each cultivar was compared with the mean value (horizontal line) using the $t$-test. In the case of FRAP variable, Wilcoxon test was used to compare each variety with the median value (horizontal line). Correlation test and analysis of variance were performed using the RStudio software, version 1.2.5033 [36], and descriptive statistics, normality tests, and the PCA analysis were performed using the MS Excel and XLSTAT package program [37].

\section{Results and Discussion}

The determined values of free radical scavenging activity using $\mathrm{DPPH}^{\circ}$ method were in the range 0.993-1.878 $\mu \mathrm{mol} \mathrm{TE/g} \mathrm{DM} \mathrm{(Table} \mathrm{1).} \mathrm{The} \mathrm{values} \mathrm{determined}$ in two different white lupin cultivars by [38] are higher (3.51 and $6.78 \mu \mathrm{mol} \mathrm{TE} / \mathrm{g} \mathrm{DM})$. On the other hand, [39] reported lower values in white lupin seeds $(0.153-0.195 \mathrm{mg} \mathrm{TE} / \mathrm{g} \mathrm{DM}$, i.e., $0.612-0.78 \mu \mathrm{mol} \mathrm{TE} / \mathrm{g} \mathrm{DM}$ ) compared to our results. Ranilla et al. [40] reported similar values in Peruvian and Brazilian lupin cultivars $(0.33-7.2 \mu \mathrm{mol} \mathrm{TE} / \mathrm{g} \mathrm{DM})$ to our results. The highest free radical scavenging activity was measured in cv. Alban (France) and the lowest one was determined in cv. Primorskij (Russia). In contrast, the lowest AA $(5.496 \mu \mathrm{mol} \mathrm{TE} / \mathrm{g} \mathrm{DM})$ determined using $\mathrm{ABTS}^{\bullet+}$ method was confirmed in cv. Alban (France) and the highest one $(7.924 \mu \mathrm{mol} \mathrm{TE} / \mathrm{g} \mathrm{DM})$ in cv. POP I (Poland). Our results are lower compared to values presented by [41] who recorded $71.4 \mu \mathrm{mol}$ TE/g DM) in white lupin cv. Karamać et al. [42] also presented higher AA values (53-123 $\mu \mathrm{mol} \mathrm{TE/}$ g DM) in four white lupin cultivars. Different results were obtained using FRAP method. The lowest AA value $(1.328 \mu \mathrm{mol}$ TE/g DM) was determined in cv. WTD (Poland)
TABLE 1: Antioxidant parameters of white lupin cultivars TAC (\% of inhibition); DPPH ( $\mu \mathrm{mol}$ TE/g DM), ABTS ( $\mu$ mol TE/g DM), and FRAP ( $\mu \mathrm{mol}$ TE/g DM).

\begin{tabular}{lcccc}
\hline Variety & TAC & DPPH & ABTS & FRAP \\
\hline Alban & $14.3 \pm 1.5$ & $1.88 \pm 0.2$ & $5.5 \pm 0.08$ & $1.64 \pm 0.01$ \\
Astra & $10 \pm 0.71$ & $1.32 \pm 0.09$ & $7.75 \pm 0.04$ & $1.53 \pm 0.02$ \\
Los Palacios & $10.4 \pm 0.88$ & $1.37 \pm 0.12$ & $6.66 \pm 0.04$ & $1.63 \pm 0.01$ \\
Nelly & $9.28 \pm 0.33$ & $1.22 \pm 0.04$ & $6.51 \pm 0.1$ & $1.52 \pm 0.02$ \\
POP I & $8.5 \pm 0.22$ & $1.3 \pm 0.34$ & $7.92 \pm 0.2$ & $1.62 \pm 0.01$ \\
Primorskij & $7.55 \pm 0.5$ & $1.18 \pm 0.36$ & $7.72 \pm 0.04$ & $1.61 \pm 0.03$ \\
R-933 & $8.9 \pm 0.16$ & $1.17 \pm 0.02$ & $7.61 \pm 0.04$ & $6.04 \pm 0.01$ \\
Satmarean & $8.3 \pm 0.32$ & $1.36 \pm 0.29$ & $7.09 \pm 0.08$ & $6.07 \pm 0.01$ \\
Solnečnyj & $9.18 \pm 0.93$ & $1.39 \pm 0.29$ & $6.27 \pm 0.05$ & $1.37 \pm 0.08$ \\
Weibit & $8.83 \pm 0.22$ & $1.16 \pm 0.03$ & $7.15 \pm 0.16$ & $1.74 \pm 0.04$ \\
WTD & $9.18 \pm 0.1$ & $1.21 \pm 0.01$ & $7.21 \pm 0.39$ & $1.33 \pm 0.05$ \\
\hline
\end{tabular}

and the highest one $(1.741 \mu \mathrm{molTE} / \mathrm{g} \mathrm{DM})$ in $\mathrm{cv}$. Weibit (Germany). There are little information from the literature for the explanation of different results of antioxidant activity determination using different methods. Pokorná et al. [43] reported that many antioxidants quickly reacting with peroxide radicals may react slowly or be inert to $\mathrm{DPPH} \bullet$. Also, [44] in their study confirmed that phenolic compounds having a high antioxidant activity with a given method may have low antioxidant activity with another method. According to these authors, the variability observed is due only to the method used, and thus it is difficult to compare the numerical values of antioxidant activity provided by different methods of determination.

The determined TPC in investigated lupin cultivars was in the interval 4260-5663 mg GAE/kg DM (Table 2). Siger et al. [38] reported similar values of TPC in seeds of 2 cultivars of white lupin (4915 and $6276 \mathrm{mg} \mathrm{GAE} / \mathrm{kg} \mathrm{DM}$, respectively), while [39] determined the values of TPC in 2 white lupin cultivars (4440 and $16610 \mathrm{mg}$ GAE/kg DM, respectively). Our results are comparable also with TPC values $4360-7250 \mathrm{mg}$ GAE/ $/ \mathrm{kg}$ DM determined by [42]. The average TPC in seeds of investigated lupin cultivars $5000 \mathrm{mg}$ GAE/kg DM was comparable with results of [45] but higher than total phenolic content $2839 \mathrm{mg}$ GAE/kg DM reported by [46]. The highest TPC was determined in cv. WTD (Poland), while the lowest one in cv. Nelly (Hungary).

Differences among lupin cultivars in total phenolic content and antioxidant parameters were statistically evaluated by the analysis of variance and Krukal-Wallis test (FRAP). Statistical differences were observed in all antioxidant parameters and phenolic content between the tested cultivars (Figure 1). In the case of TPC parameter, statistically higher values were observed in Alban, Satmarean, Weibit, and WTD cultivars. On the other hand, cultivar Nelly had statistically lower content of TPC compared to the other tested cultivars. AA content was statistically higher in cultivar Alban. Cultivars R-933, Satmarean, POP I, Primorskij and Weibit had statistically lower AA. In the case of ABTS, the values were very variable. Alban cultivar had statistically higher free radical scavenging activity according to DPPH method. On the other hand, cultivars R-933, Nelly and Weibit had statistically lower DPPH values. In the case of FRAP method, Kruskal-Wallis test was prepared to find 
TABle 2: Content of phenolics (mg/kg DM) and TPC (mg GAE/kg DM).

\begin{tabular}{lccccccccc}
\hline Variety & $\begin{array}{c}\text { 4-Hydroxybenzoic } \\
\text { acid }\end{array}$ & $\begin{array}{c}\text { Caffeic } \\
\text { acid }\end{array}$ & $\begin{array}{c}\text { Trans-p- } \\
\text { coumaric acid }\end{array}$ & $\begin{array}{c}\text { Trans-ferulic } \\
\text { acid }\end{array}$ & Myricetin & Quercetin & Apigenin & Genistein & TPC \\
\hline Alban & $13.1 \pm 0.34$ & $743 \pm 4.07$ & $6.55 \pm 0.22$ & $11.8 \pm 0.32$ & $21.2 \pm 0.33$ & $1.08 \pm 0.33$ & $1.87 \pm 0.32$ & $1.77 \pm 0.32$ & $5393 \pm 80.6$ \\
Astra & $8.74 \pm 0.16$ & $522 \pm 0.16$ & $3.44 \pm 0.16$ & $8.74 \pm 0.16$ & $16.2 \pm 0.16$ & $1.44 \pm 0.45$ & $1.62 \pm 0.2$ & $1.67 \pm 0.16$ & $4795 \pm 119$ \\
Los & $5.63 \pm 0.4$ & $464 \pm 0.43$ & $3.33 \pm 0.4$ & $7.63 \pm 0.57$ & $11.2 \pm 0.4$ & $0.64 \pm 0.4$ & $1.27 \pm 0.4$ & $1.47 \pm 0.4$ & $5139 \pm 121$ \\
Palacios & & & & & & & & & \\
Nelly & $17.8 \pm 0.49$ & $766 \pm 1.45$ & $5.69 \pm 0.38$ & $9.72 \pm 0.49$ & $20.7 \pm 0.38$ & $0.79 \pm 0.48$ & $2.66 \pm 0.42$ & $1.78 \pm 0.49$ & $4260 \pm 107$ \\
POP I & $9.53 \pm 0.37$ & $507 \pm 0.42$ & $2.94 \pm 0.41$ & $6.97 \pm 0.64$ & $15.1 \pm 0.44$ & $1.2 \pm 0.43$ & $1.64 \pm 0.43$ & $2 \pm 0.62$ & $4699 \pm 237$ \\
Primorskij & $6.08 \pm 0.33$ & $486 \pm 0.29$ & $2.67 \pm 0.24$ & $6.58 \pm 0.34$ & $13.5 \pm 0.19$ & $1.19 \pm 0.53$ & $1.59 \pm 0.25$ & $1.43 \pm 0.14$ & $4940 \pm 189$ \\
R-933 & $8.81 \pm 0.41$ & $545 \pm 1.13$ & $3.29 \pm 0.4$ & $5.18 \pm 0.63$ & $13.9 \pm 0.41$ & $0.65 \pm 0.41$ & $1.1 \pm 0.4$ & $1.8 \pm 0.77$ & $4627 \pm 23.5$ \\
Satmarean & $10.5 \pm 0.37$ & $524 \pm 0.57$ & $2.47 \pm 0.4$ & $6.81 \pm 0.4$ & $13.7 \pm 0.4$ & $0.94 \pm 0.45$ & $1.38 \pm 0.4$ & $1.94 \pm 0.53$ & $5486 \pm 30.6$ \\
Solnečnyj & $8.48 \pm 0.16$ & $497 \pm 0.16$ & $3.37 \pm 0.16$ & $7.63 \pm 0.16$ & $13.9 \pm 0.29$ & $0.99 \pm 0.16$ & $1.93 \pm 0.17$ & $1.64 \pm 0.16$ & $4774 \pm 108$ \\
Weibit & $9.58 \pm 0.32$ & $580 \pm 0.25$ & $6.49 \pm 0.15$ & $7.84 \pm 0.4$ & $17.8 \pm 0.24$ & $0.65 \pm 0.24$ & $1.49 \pm 0.38$ & $1.49 \pm 0.24$ & $5224 \pm 93.6$ \\
WTD & $5.39 \pm 0.16$ & $443 \pm 0.48$ & $4.09 \pm 0.55$ & $5.89 \pm 0.72$ & $13.7 \pm 0.16$ & $0.8 \pm 0.18$ & $1.4 \pm 0.16$ & $1.5 \pm 0.16$ & $5663 \pm 74.5$ \\
\hline
\end{tabular}

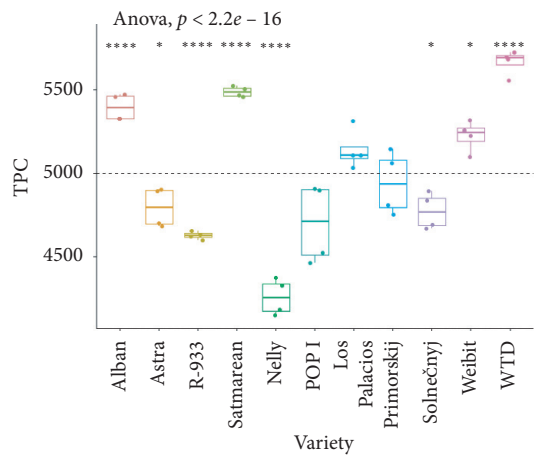

(a)

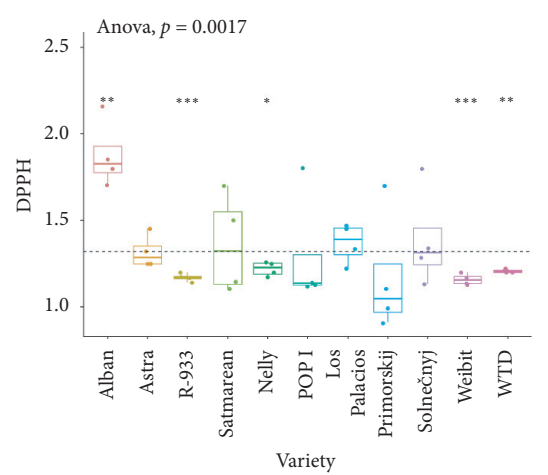

(c)

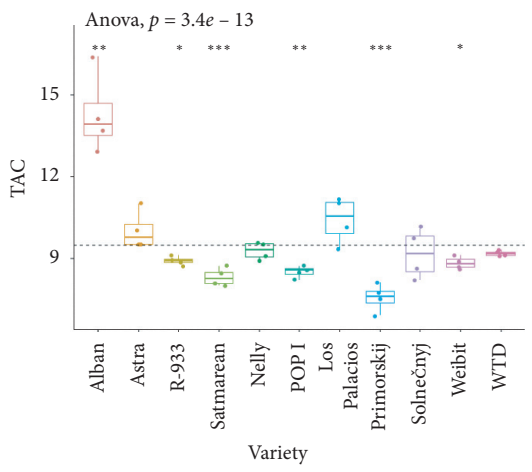

(b)

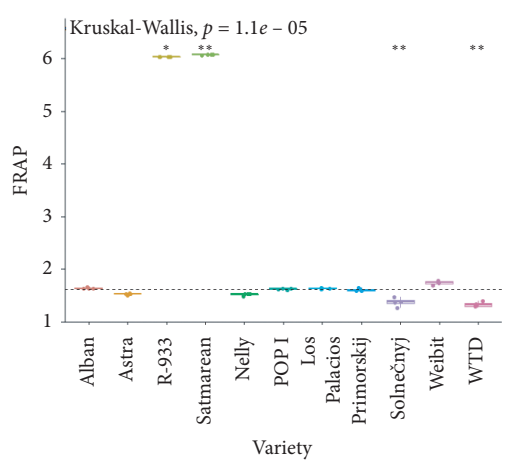

(d)

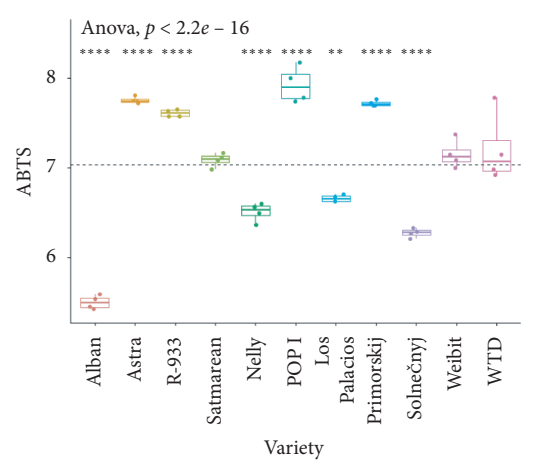

(e)

FiguRE 1: Statistical differences in antioxidant parameters between the investigated white lupin cultivars. 
significant differences between the tested cultivars. Cultivars R-933 and Satmarean had statistically higher content of FRAP.

Legumes are considered as a remarkable food source of biologically valuable components which can positive affect many physiological and metabolic processes [47]. Phenolics present in legume seeds are represented by phenolic acids, flavonoids, and condensed tannins [48]. Our research was focused on the content of selected phenolic acids (4hydroxybenzoic, caffeic, trans- $p$-coumaric, and trans-ferulic acid), which was determined in seeds of all investigated white lupin cultivars. The average values of investigated phenolic acids are displayed in Table 2. The determined values ranged as follows: 4-hydroxybenzoic acid, $5.39-17.76 \mathrm{mg} / \mathrm{kg}$ DM; caffeic acid, $442.90-766.20 \mathrm{mg} / \mathrm{kg}$ $\mathrm{DM}$; trans-p-coumaric acid, $2.47-6.44 \mathrm{mg} / \mathrm{kg} \mathrm{DM}$; and trans-ferulic acid, $5.18-11.80 \mathrm{mg} / \mathrm{kg}$ DM (Table 2).

The highest content of 4-hydroxybenzoic as well as caffeic acid was determined in cv. Nelly (Hungary), while the lowest content of both of these phenolic acids was found out in cv. WTD (Poland). Cultivar Alban (France) was the richest in trans-p-coumaric as well as trans-ferulic acid, while seeds of cv. Satmarean (Romania) contained the lowest amount of trans-p-coumaric acid and seeds of cv. R-933 (Poland) had the lowest content of trans-ferulic acid. Caffeic acid seems to be the dominant phenolic acid in the investigated cultivars of white lupin. On the other hand, p-hydroxybenzoic acid is the main phenolic acid in L. albus according to [49]. Differences among lupin cultivars in phenolic acids content were statistically evaluated (Figure 2). Analysis of variation showed that the cultivars Alban and Nelly are a statistically rich sources of phenolic acids compared to other cultivars. Cultivar Weibit is a good source of caffeic acid and trans-p-coumaric acid. In general, it can be concluded that other cultivars are not statistically significant sources of phenolic acids.

Siger et al. [38] determined in two cultivars of white lupin seeds higher content of $p$-hydroxybenzoic acid (22.77 and $27.82 \mathrm{mg} / \mathrm{kg}$ ) but lower content of caffeic acid $(0.58$ and $0.09 \mathrm{mg} / \mathrm{kg})$ as well as $p$-coumaric acid $(0.11$ and $0.18 \mathrm{mg} / \mathrm{kg})$ compared to our results. The presence of genistein and main cinnamic acids derivatives (ferulic, caffeic, rosmarinic, and coumaric acids) in germinated and also in ungerminated lupin seeds was confirmed by [45] using FTIR spectra. Many studies were focused on phenolics composition of other kinds of legumes. Dueñas et al. [50] determined in lentils $p$ hydroxybenzoic acid in an amount of $3.25 \mu \mathrm{g} / \mathrm{g}$ and [51] even only $1.90 \mu \mathrm{g} / \mathrm{g}$, whereas [52] detected $p$-hydroxybenzoic acid $(15.7-44.9 \mu \mathrm{g} / \mathrm{g})$ in 11 lentil cultivars; $p$-hydroxybenzoic acid $(19.2$ to $60.5 \mathrm{mg} / \mathrm{kg})$ was reported in seeds of six chickpea varieties, while in seeds of six field pea varieties, it was present in amount 45.4 to $101.7 \mathrm{mg} / \mathrm{kg}$ [53]. The average content of $p$-hydroxybenzoic acid in our lupin cultivars was $9.41 \mathrm{mg} / \mathrm{kg}$ and is comparable to $p$-hydroxybenzoic acid content in uncolored and colored bean $(4.03 \mu \mathrm{g} / \mathrm{g}$ and $12.20 \mu \mathrm{g} / \mathrm{g}$, respectively) reported by [54]. According to [50] lentils contain $5.74 \mu \mathrm{g} / \mathrm{g}$ of trans- $p$-coumaric acid, which is comparable value to the average content of this phenolic acid in our lupin cultivars $(3.98 \mathrm{mg} / \mathrm{kg})$. On the other hand, [55] reported higher amount of trans- $p$-coumaric acid $(37.3 \mu \mathrm{g} / \mathrm{g})$ in green lentil. Trans-ferulic acid (8.95, respectively, $11.80 \mu \mathrm{g} / \mathrm{g}$ ) was the main identified hydroxycinnamic acid in uncolored and colored bean by [54] and $10.1 \mu \mathrm{g} / \mathrm{g}$ was determined in green lentil by [55]. These values are comparable to those determined in our lupin cultivars with the average content of trans-ferulic acid $7.67 \mathrm{mg} / \mathrm{kg}$. In two different lentil cultivars, also caffeic acid (2.52, respectively, $0.25 \mu \mathrm{g} / \mathrm{g}$ ) was detected [56]. Luthria and Pastor-Corrales [57] determined caffeic acid $(11 \mathrm{mg} / \mathrm{kg})$ in two cultivars of commonly consumed dry bean. Yao et al. [58] analyzed sixteen legumes in China and detected caffeic acid in broad bean, pea, adzuki bean, hyacinth bean, rice bean, and soybean $(7.8,5.3,11.2$, $9.6,7.3$, and $6.3 \mathrm{mg} / \mathrm{kg}$, respectively). The average content of caffeic acid in our lupin cultivars $(552 \mathrm{mg} / \mathrm{kg}$ ) is significantly higher compared to other legumes mentioned above. Our analysis included also the determination of selected flavonoid content in investigated white lupin cultivars (Table 2). The content of flavonoids in lupin cultivars was as follows: myricetin, $11.15-21.19 \mathrm{mg} / \mathrm{kg}$ DM; quercetin, $0.64-1.20 \mathrm{mg} /$ $\mathrm{kg} \mathrm{DM}$; apigenin, $1.10-2.61 \mathrm{mg} / \mathrm{kg} \mathrm{DM}$; and genistein, $1.34-1.78 \mathrm{mg} / \mathrm{kg}$ DM (Figure 3). Differences among lupin cultivars in flavonoids content were statistically evaluated. In general, it can be concluded that the differences between the contents of the flavonoids tested are not significant except for the content of myricetin $(p<2.2 e-16)$. Cultivars Nelly and Solnečnyj had statistically higher content of apigenin.

According to [59], genistein content in stems of white lupin varies in a large range $(0.2-27.44 \mathrm{mg} / \mathrm{kg})$. In leaves of white lupin, [60] determined $59.2 \mathrm{mg} / \mathrm{kg}$ of genistein. These authors also detected genistein in seeds of pea, bean, lentil, and fava bean $(45.8,16.3-45.1,25.0$, and $19.9 \mathrm{mg} / \mathrm{kg}$, respectively).

The relationships between the tested variables are displayed using the Pearson correlation matrix in Figure 4. Inverse relationships between ABTS and myricetin, caffeic acid, 4-hydroxybezoic acid, trans-p-coumaric acid, TAC, trans-ferulic acid, and DPPH were observed. Inverse relationship was also observed between trans-ferulic acid, apigenin and TPC, FRAP and trans-ferulic acid, TPC and apigenin, and 4-hydroxybenzoic acid. Strong and moderate positive relationships were observed between phenolic acids. Trans-ferulic acid showed positive relationships with TAC, trans-p-coumaric acid, apigenin, 4-hydroxybenzoic acid, caffeic acid, and myricetin. There were observed strong positive relationship between caffeic acid, myricetin, and trans-p-coumaric acid.

Legumes are the basis of human diet in many regions. Therefore, the research is oriented predominantly on commonly used legume species such as bean, lentil, chickpea, pea, or soybean. López et al. [61] determined in raw seeds of dark beans $3.41 \mathrm{mg} / \mathrm{kg}$ of quercetin, and in germinated seeds, they detected also myricetin $(3.97 \mathrm{mg} / \mathrm{kg})$. In Mexican common bean seeds, $10.9 \mathrm{mg} / \mathrm{kg}$ of quercetin was determined by [62]. Giusti et al. [63] analyzed 36 species of legumes. Quercetin was detected only in black eyed beans, crimson lentils, and black lentils $(2.0,7.5$, and $5.4 \mathrm{mg} / \mathrm{kg}$, respectively). Our lupin samples contained comparable amount of quercetin to black eyed beans. 


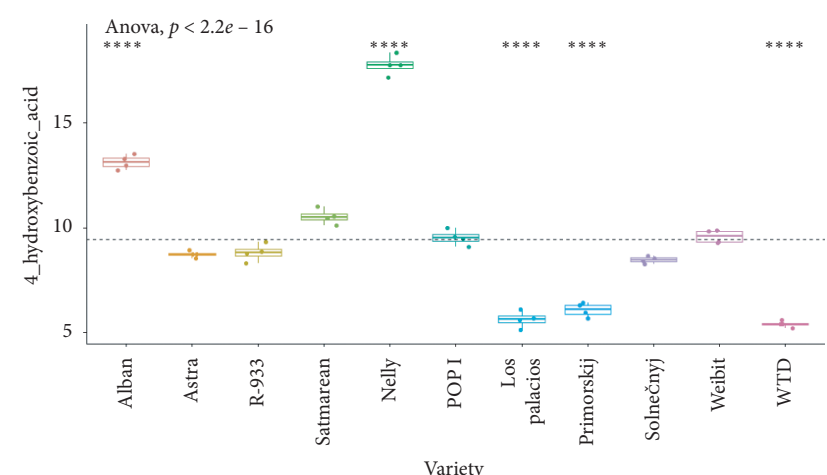

(a)

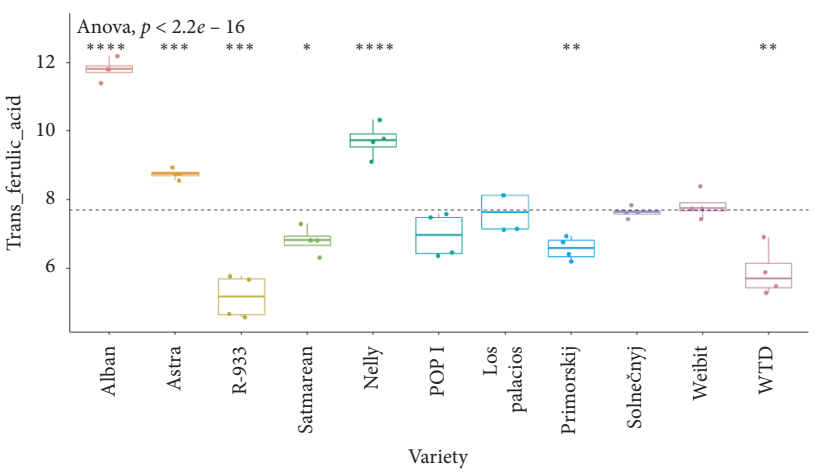

(c)

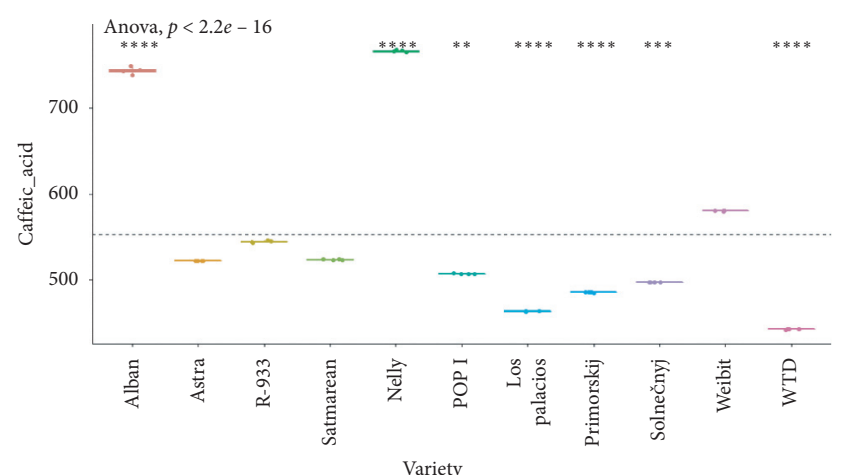

(b)

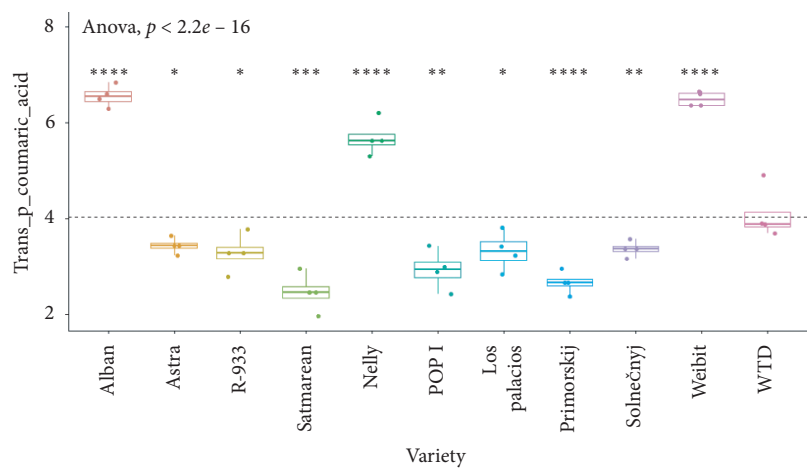

(d)

FIGURE 2: Statistical differences in phenolic acid contents between the investigated white lupin cultivars.

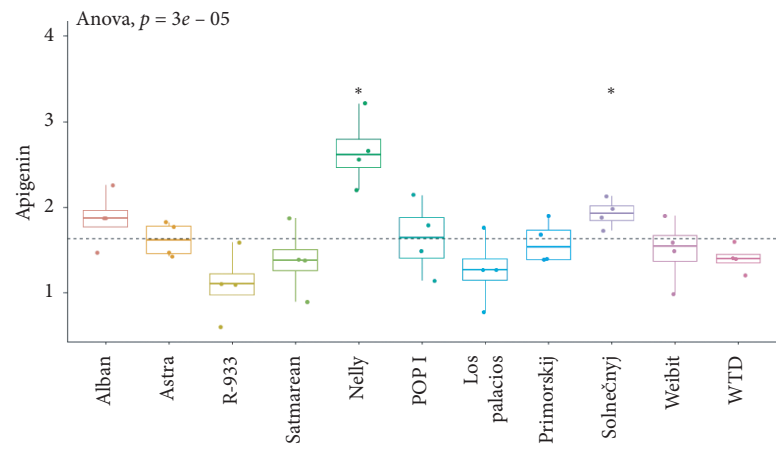

(a)

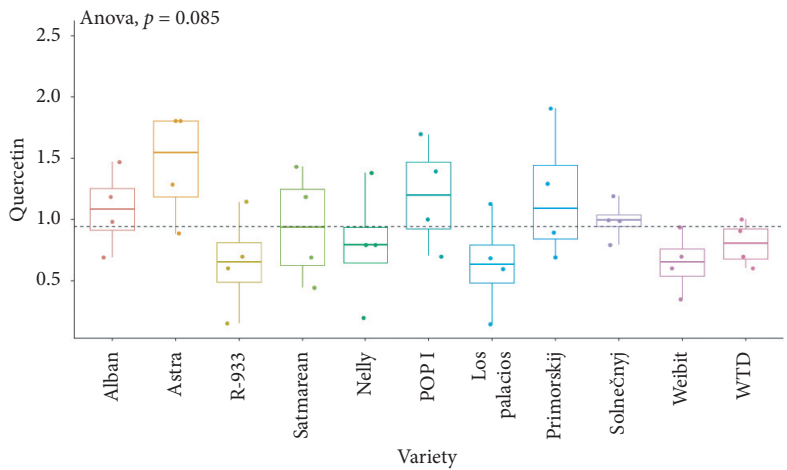

(c)

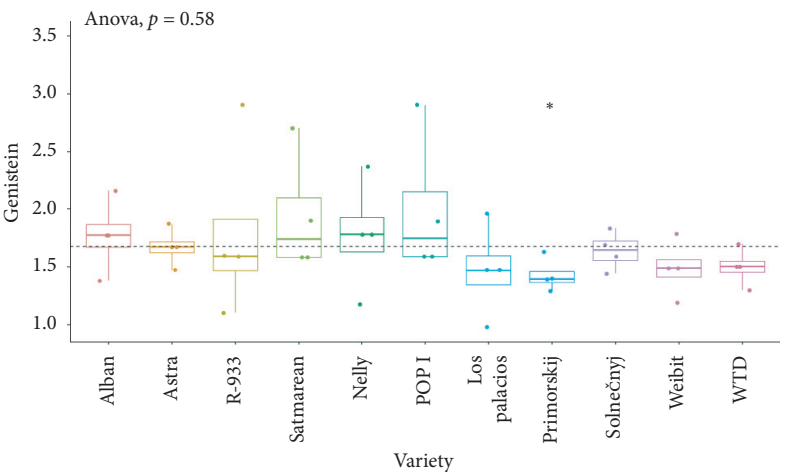

(b)

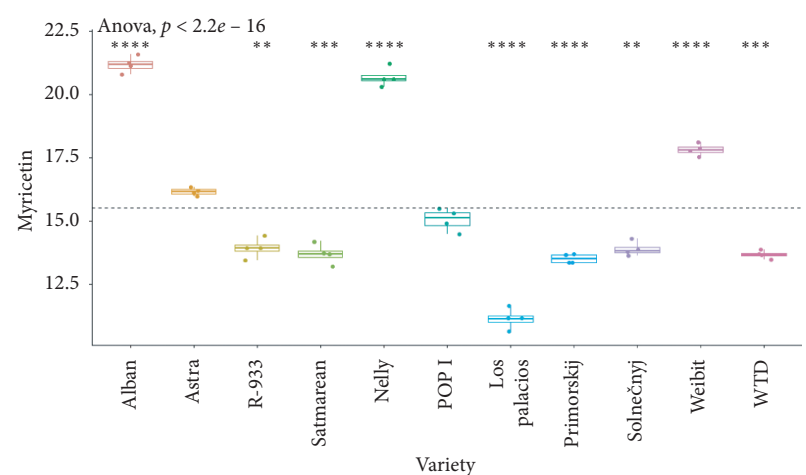

(d)

FIgURE 3: Statistical differences in flavonoid content between the investigated white lupin cultivars. 


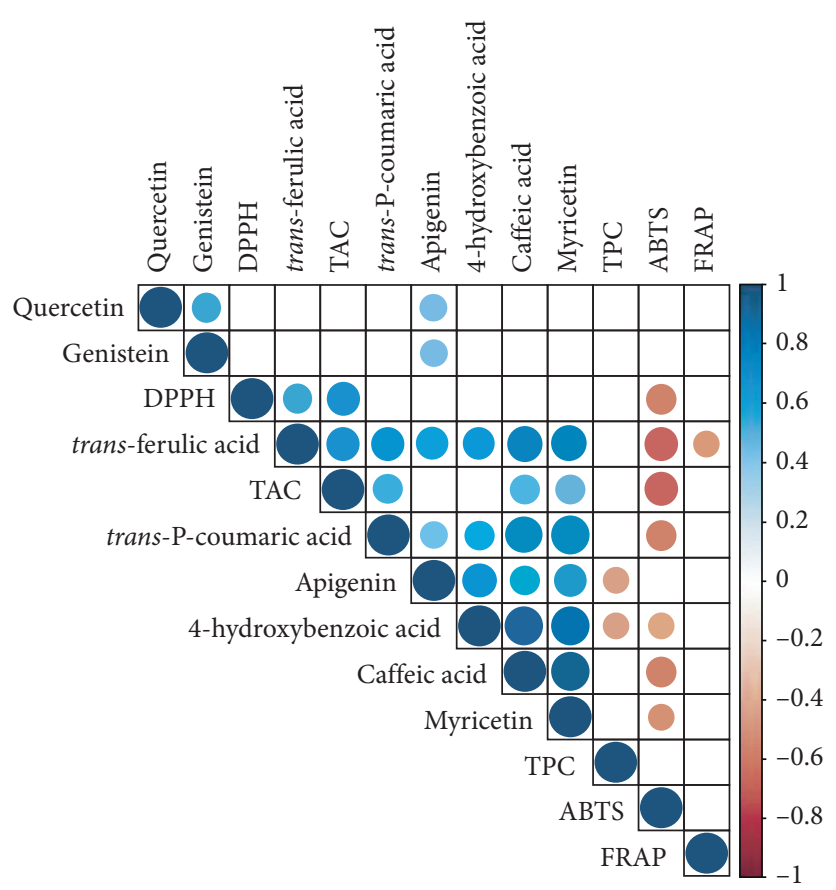

FIgURE 4: Pearson correlation matrix: the correlations between the investigated variables.

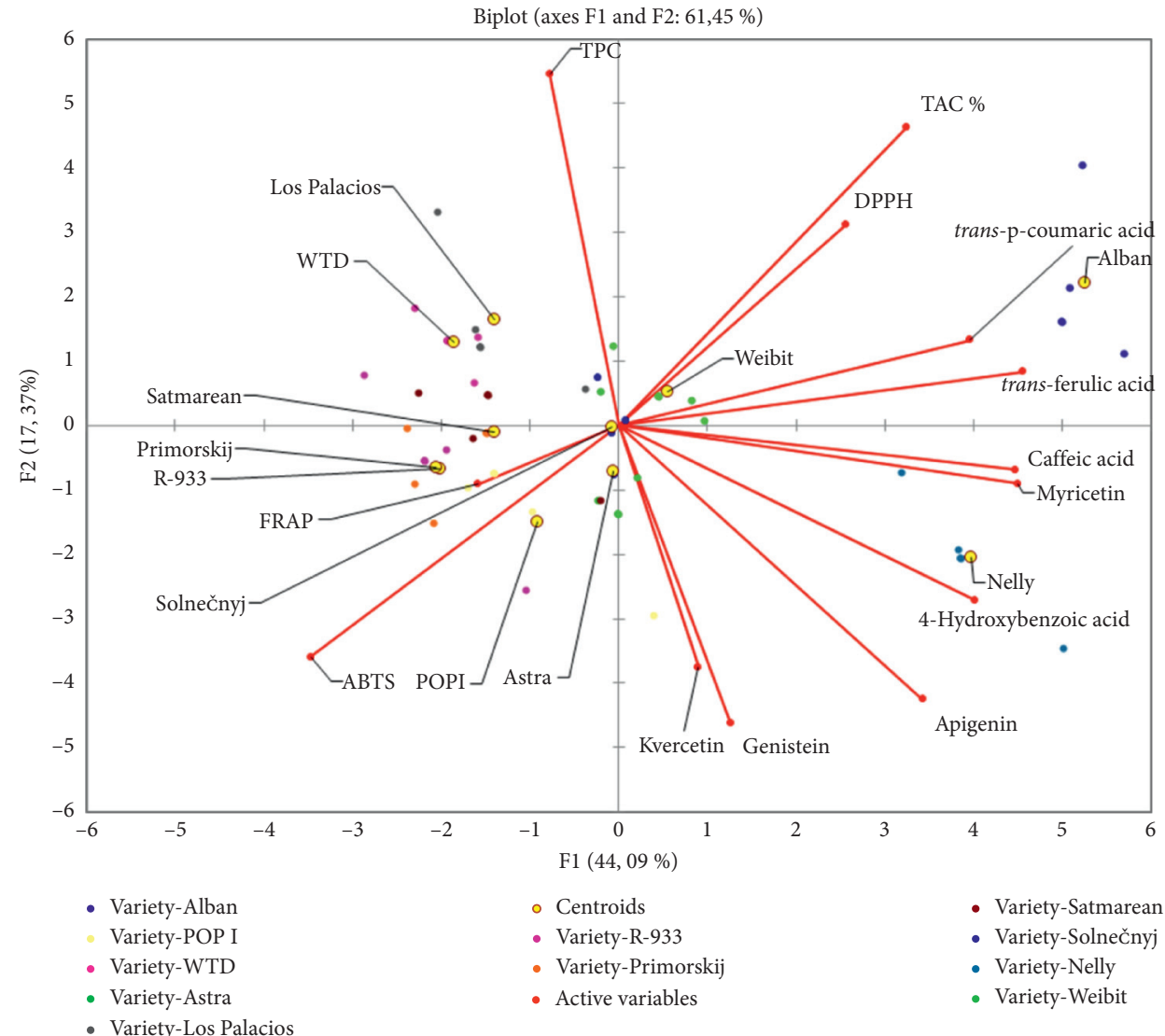

Figure 5: Results from PCA analysis-plot of the first two PC loadings. 
Principal component analysis was prepared to extract the important information from the dataset and to display the pattern of similarity of the observations and of the variables as points in 2D plot (Figure 5). Kaiser-Meyer-Olkin (KMO) test of sampling adequacy showed middling suitability of the data for the complete model $(\mathrm{KMO}=0.7124)$. Bartlett's test of sphericity was significant $($ chi-square $($ observed $)=561.808$, chi-square $($ critical $)=$ 99.6169, $p \leq 0.0001$, and alpha $=0.05$ ), indicating that the data was likely factorable. The PCA revealed that $61.46 \%$ of the total variation embodied in 13 variables could be effectively condensed into and explained by the first two principal components (PCs), with eigenvalues of 5.73 and 2.25 , respectively. The PC1, accounting for $44.09 \%$ of the inertia, contrasted with FRAP and ABTS with trans-ferulic acid, caffeic acid, and myricetin, whereas PC2, explaining $17.37 \%$ of the inertia, clearly reflected the different content of TPC contrasting with quercetin and genistein content. Figure 5 shows a 2D map for PC1 and PC2, in which the tested variables are clustered around the centroids. The centroids present factor scores and squared cosines, which are the coordinates and representation qualities, respectively. The most important variables for F1 are trans-ferulic acid, myricetin, and caffeic acid and for F2 are TPC and genistein. The variety Alban is mostly characterized by transp-coumaric acid and trans-p-ferulic acid, whereas variety Nelly is characterized by the 4-hydroxybenzoic acid. These two varieties have an increased content of phenolic acids. This fact is also confirmed by the results of the ANOVA analysis. On the other hand, the varieties Primorskij, Satmarean, and R-933 are very similar and characterized mostly by antioxidant parameters of FRAP and ABTS. High ABTS values are typical for the POP I variety. It can be concluded that PCA analysis cannot strictly separate the varieties Solnečnyj, Astra, and Weibit.

It could be concluded that the antioxidant activity of the extracts depends on extraction conditions, as well as on the composition of the phenolic compounds and flavonoids. Proportion of individual phenolics or flavonoids and their chemical structure belong to determining factors affecting the antioxidant properties of plant. The antioxidant activity could be affected also by other present components with their synergistic or antagonistic effects.

\section{Conclusions}

Our study was focused on the content of bioactive phenolic compounds in seeds of white lupin cultivars of different origin countries. In our lupin samples an interesting content of phenolic compounds (especially caffeic acid and myricetin) with a reported positive effect on the human organism, was determined. Based on our results Alban and Nelly cultivars seem to be the most valuable source of lupin antioxidants. These two cultivars originated from France (cv. Alban) and Hungary (cv. Nelly) are rich in phenolic acids as well as flavonoids content. White lupin cultivars, Alban and Nelly, were the richest sources of 4-hydroxybenzoic acid, caffeic acid, and trans-ferulic acid, while cv. Alban also contained the highest amount of trans-p-coumaric acid. At the same time in Alban and Nelly cultivars the highest contents of myricetin and apigenin were detected. This remarkable content of phytochemicals with a potential positive effect on the human health predetermines these two cultivars to be utilised in production of innovative functional foods.

In addition, white lupin is the crop resistant to unfavourable climate condition. Based on above-mentioned properties of lupin seeds it can be concluded that white lupin is really a promising food source of antioxidants and has a potential to be widely used in the production of foods with the added value.

\section{Data Availability}

The data used to support the findings of this study are available from the corresponding author upon request.

\section{Conflicts of Interest}

The authors declare that they have no conflicts of interest.

\section{Acknowledgments}

This publication was supported by the Operational Program Integrated Infrastructure within the project: DemandDriven Research for the Sustainable and Innovative Food, Drive4SIFood 313011V336, cofinanced by the European Regional Development Fund.

\section{Supplementary Materials}

The chromatograms of standards are presented: 4-hydroxybenzoic acid (A), caffeic acid (B), trans-p-coumaric acid (C), trans-ferulic acid (D), apigenin (E), myricetin (F), quercetin $(\mathrm{G})$, and genistein $(\mathrm{H})$ as well as the example of chromatograms of one of investigated lupine cultivars (WTD). (Supplementary Materials)

\section{References}

[1] M. J. Messina, "Legumes and soybeans: overview of their nutritional profiles and health effects," The American Journal of Clinical Nutrition, vol. 70, no. 3, pp. 439-450, 1999.

[2] R. N. Tharanathan and S. Mahadevamma, "Grain legumes-a boon to human nutrition," Trends in Food Science \& Technology, vol. 14, no. 12, pp. 507-518, 2003.

[3] R. Knigh, Ed., Current Plant Science and Biotechnology in Agriculture. Linking Research and Marketing Opportunities for Pulses in the $21^{\text {st }}$ Century, Kluwer Academic Publishers, Berlin, Germany, 2000.

[4] M. Bouchenak and M. Lamri-Senhadji, "Nutritional quality of legumes, and their role in cardiometabolic risk prevention: a review," Journal of Medicinal Food, vol. 16, no. 3, 2013.

[5] M. Atnaf, D. Wegary, T. Kassahun et al., "Exploring forgotten opportunity: white Lupin development for food, feed, cash, health, and soil fertility management in Ethiopia," Cogent Environmental Science, vol. 6, no. 1, 112 pages, 2020.

[6] A. Mikić, B. Cupina, V. Mihailović et al., "Intercropping white (Lupinus albus) and Andean (Lupinus mutabilis) lupins with other annual cool season legumes for forage production," South African Journal of Botany, vol. 89, pp. 296-300, 2013. 
[7] C. Arncken, M. Klaiss, M. Wendling, and M. Messmer, "Cultivation of white lupin," Legumes Translated Practice Note 4, Research Institute of Organic Agriculture FiBL, Frick, Switzerland, 2020.

[8] V. Mazur, K. Mazur, and H. Pantsyreva, "Influence of the technological aspects growing on quality composition of seed white lupine (Lupinus albus L.) in the Forest Steppe of Ukraine," Ukrainian Journal of Ecology, vol. 9, pp. 50-55, 2019.

[9] M. Fernández-Pascual, J. J. Pueyo, M. R. de Felipe, M. P. Golvano, and M. M. Lucas, "Singular features of the bradyrhizobium-lupinus symbiosis," Dynamic Plant, vol. 1, no. 1, pp. 1-16, 2007.

[10] J. Prusinski, "White lupin (Lupinus albus L.) - nutritional and health values in human nutrition - a review," Czech Journal of Food Sciences, vol. 35, pp. 95-105, 2017.

[11] A. Sujak, A. Kotlarz, and W. Strobel, "Compositional and nutritional evaluation of several lupin seeds," Food Chemistry, vol. 98, pp. 711-719, 2005.

[12] Z. Kohajdová, J. Karovičová, and S. Schmidt, "Lupin composition and possible use in bakery - a review," Czech Journal of Food Sciences, vol. 29, no. 3, pp. 203-211, 2011.

[13] M. Erbaş, M. Certel, and M. K. Uslu, "Some chemical properties of white lupin seeds (Lupinus albus L.)," Food Chemistry, vol. 89, no. 3, pp. 341-345, 2005.

[14] E. R. Grela, W. Samolińska, B. Kiczorowska, R. Klebaniuk, and P. Kiczorowski, "Content of minerals and fatty acids and their correlation with phytochemical compounds and antioxidant activity of leguminous seeds," Biological Trace Element Research, vol. 180, no. 2, pp. 338-348, 2017.

[15] V. Sebastiá, R. Barberá, R. Farré, and M. J. Lagarda, "Effects of legume processing on calcium, iron and zinc contents and dialysabilities," Journal of the Science of Food and Agriculture, vol. 81, no. 12, pp. 1180-1185, 2001.

[16] D. Zielinska, J. Frias, M. K. Piskuła, H. Kozłowska, H. Zielinski, and C. Vidal-Valverde, "Evaluation of the antioxidant capacity of lupin sprouts germinated in the presence of selenium," European Food Research and Technology, vol. 227, no. 6, pp. 1711-1720, 2008.

[17] K. Sedláková, E. Straková, P. Suchý, J. Krejcarová, and I. Herzig, "Lupin as a perspective protein plant for animal and human nutrition - a review," Acta Veterinaria Brno, vol. 85, no. 2, pp. 165-175, 2016.

[18] N. J. Pollard, F. L. Stoddard, Y. Popineau, C. W. Wrigley, and F. MacRitchie, "Lupin flours as additives: dough mixing, breadmaking, emulsifying, and foaming," Cereal Chemistry Journal, vol. 79, no. 5, pp. 662-669, 2002.

[19] G. Dervas, G. Doxastakis, S. Hadjisavva-Zinoviadi, and N. Triantafillakos, "Lupin flour addition to wheat flour doughs and effect on rheological properties," Food Chemistry, vol. 66, no. 1, pp. 67-73, 1999.

[20] M. M. Lucas, F. L. Stoddard, P. Annicchiarico et al., "The future of lupin as a protein crop in Europe," Frontiers in Plant Science, vol. 6, p. 705, 2015.

[21] M. Kroc, W. Rybiński, P. Wilczura et al., "Quantitative and qualitative analysis of alkaloids composition in the seeds of a white lupin (Lupinus albus L.) collection," Genetic Resources and Crop Evolution, vol. 64, no. 8, pp. 1853-1860, 2017.

[22] D. M. Martirosyan and J. Singh, "A new definition of functional food by FFC: what makes a new definition unique?" Functional Foods in Health and Disease, vol. 5, no. 6, pp. 209-223, 02015.

[23] F. V. Romeo, S. Fabroni, G. Ballistreri et al., "Characterization and antimicrobial activity of alkaloid extracts from seeds of different genotypes of Lupinus spp," Sustainability, vol. 10, no. 3, pp. 6-10, 2018.

[24] O. Dubois, C. Allanic, C. L. Charvet et al., "Lupin (Lupinus spp.) seeds exert anthelmintic activity associated with their alkaloid content," Scientific Reports, vol. 9, no. 1, pp. 9070-9112, 2019.

[25] R. Bouchoucha, M. Kacem Ben, M. Bouchoucha et al., "Antihyperglycemic and anti-hyperlipidemic effects of Lupinus albus in type 2 diabetic patients: a randomized double-blind, placebo-controlled clinical trial," International Journal of Pharmacology, vol. 12, no. 8, pp. 830-837, 2016.

[26] C. J. Walsh, C. M. Guinane, P. W. O’Toole, and P. D. Cotter, "Beneficial modulation of the gut microbiota," FEBS Letters, vol. 588, no. 22, pp. 4120-4130, 2014.

[27] C. Pavanello, C. Lammi, M. Ruscica et al., "Effects of a lupin protein concentrate on lipids, blood pressure and insulin resistance in moderately dyslipidaemic patients: a randomised controlled trial," Journal of Functional Foods, vol. 37, pp. 8-15, 2017.

[28] K. Mazumder, K. Chinkwo, A. Farahnaky, and P. Kerr, “The potential of lupin as a functional food for the prevention of diabetes and pancreatic cancer," in Proceedings of the Abstract from 68th Australasian Grain Science Conference, Wagga Wagga, Australia, September 2018.

[29] N. Rajurkar and S. Hande, "Estimation of phytochemical content and antioxidant activity of some selected traditional Indian medicinal plants," Indian Journal of Pharmaceutical Sciences, vol. 73, no. 2, pp. 146-151, 2011.

[30] J. Lachman, D. Proněk, A. Hejtmánková, J. Dudjak, V. Pivec, and K. Faitová, "Total polyphenol and main flavonoid antioxidants in different onion (Allium cepa L.) varieties," Horticultural Science, vol. 30, no. 4, pp. 142-147, 2003.

[31] W. Brand-Williams, M. E. Cuvelier, and C. Berset, "Use of a free radical method to evaluate antioxidant activity," $L W T$ Food Science and Technology, vol. 28, no. 1, pp. 25-30, 1995.

[32] R. Re, N. Pellegrini, A. Proteggente et al., "Antioxidant activity applying an improved ABTS radical cation decolorization assay," Free Radical Biology \& Medicine, vol. 26, no. 9-10, pp. 1231-1237, 1999.

[33] C. Pedersen, J. Kyle, A. Jenkinson, P. Gardner, D. McPhail, and G. Duthie, "Effects of blueberry and cranberry juice consumption on the plasma antioxidant capacity of healthy female volunteers," European Journal of Clinical Nutrition, vol. 54, no. 5, pp. 405-408, 2000.

[34] M. Gabriele, L. Pucci, J. Árvay, and V. Longo, "Anti-inflammatory and antioxidant effect of fermented whole wheat on TNF $\alpha$-stimulated HT-29 and NF- $\kappa \mathrm{B}$ signaling pathway activation," Journal of Functional Foods, vol. 45, pp. 392-400, 2018.

[35] R. Russo, L. Pucci, L. Giorgetti et al., "Polyphenolic characterisation of plant mixture (Lisosan Reduction) and its hypocholesterolaemic effect in high fat diet-fed mice," Natural Product Research, vol. 33, no. 5, pp. 651-658, 2019.

[36] RStudio Team, RStudio: Integrated Development for $R$, RStudio, Inc., Boston, MA, USA, 2015, http://www.rstudio. $\mathrm{com} /$.

[37] Addinsoft XLSTAT, Analyse de données et statistique avec MS Excel, Addinsoft, New York, NY, USA, 2014.

[38] A. Siger, J. Czubinski, P. Kachlicki, K. Dwiecki, E. LampartSzczapa, and M. Nogala-Kalucka, "Antioxidant activity and phenolic content in three lupin species," Journal of Food Composition and Analysis, vol. 25, no. 2, pp. 190-197, 2012.

[39] S. Wang and J. Clements, "Antioxidant activities of lupin seeds," in Lupins for Health and Wealth, J. A. Palta and 
J. B. Berger, Eds., pp. 546-551, Fremantle, Western Australia, 2008.

[40] L. G. Ranilla, M. I. Genovese, and F. M. Lajolo, "Isoflavones and antioxidant capacity of Peruvian and Brazilian lupin cultivars," Journal of Food Composition and Analysis, vol. 22, no. 5, pp. 397-404, 2009.

[41] C. Martínez-Villaluenga, H. Zieliński, J. Frias, M. K. Piskuła, H. Kozłowska, and C. Vidal-Valverde, "Antioxidant capacity and polyphenolic content of high-protein lupin products," Food Chemistry, vol. 112, no. 1, pp. 84-88, 2009.

[42] M. Karamać, H. H. Orak, R. Amarowicz, A. Orak, and W. Piekoszewski, "Phenolic contents and antiooxidant capacities of wild and cultivated whit lupin (Lupinus albus L.) seeds," Food Chemistry, vol. 258, pp. 1-7, 2018.

[43] J. Pokorná, P. R. Venskutonis, V. Kraujalis et al., "Comparison of different methods of antioxidant activity evaluation of green and roastC. ArabicaandC. Robustacoffee beans," Acta Alimentaria, vol. 44, no. 3, pp. 454-460, 2015.

[44] M. d. S. M. Rufino, R. E. Alves, E. S. de Brito, J. Pérez-Jiménez, F. Saura-Calixto, and J. Mancini-Filho, "Bioactive compounds and antioxidant capacities of 18 non-traditional tropical fruits from Brazil," Food Chemistry, vol. 121, no. 4, pp. 996-1002, 2010.

[45] C. Danciu, I. Pavel, R. Babuta et al., "Total phenolic content, FTIR analysis, and antiproliferative evaluation of lupin seeds harvest from western Romania," Annals of Agricultural and Environmental Medicine, vol. 24, no. 4, pp. 726-731, 2017.

[46] E. R. Grela, B. Kiczorowska, W. Samolińska et al., "Chemical composition of leguminous seeds: part I-content of basic nutrients, amino acids, phytochemical compounds, and antioxidant activity," European Food Research and Technology, vol. 243, no. 8, pp. 1385-1395, 2017.

[47] B. Singh, J. P. Kaur, and N. Singh, "Phenolic composition and antioxidant potential of grain legume seeds: a review," Food Research International, vol. 101, pp. 1-16, 2017.

[48] R. Amarowicz and R. B. Pegg, "Legumes as a source of natural antioxidants," European Journal of Lipid Science and Technology, vol. 110, no. 10, pp. 865-878, 2008.

[49] M. A. Ruiz-López, L. Barrientos-Ramírez, P. M. García-López et al., "Nutritional and bioactive compounds in Mexican lupin beans species: a mini-review," Nutrients, vol. 11, no. 8, p. 1785, 2019.

[50] M. Dueñas, T. Hernández, and I. Estrella, "Changes in the content of bioactive polyphenolic compounds of lentils by the action of exogenous enzymes. Effect on their antioxidant activity," Food Chemistry, vol. 101, no. 1, pp. 90-97, 2007.

[51] Y. Aguilera, M. Dueñas, I. Estrella et al., "Evaluation of phenolic profile and antioxidant properties of Pardina lentil as affected by industrial dehydration," Journal of Agricultural and Food Chemistry, vol. 58, no. 18, pp. 10101-10108, 2010.

[52] B. Xu and S. K. C. Chang, "Phenolic substance characterization and chemical and cell-based antioxidant activities of 11 lentils grown in the northern United States," Journal of Agricultural and Food Chemistry, vol. 58, no. 3, pp. 1509-1517, 2010.

[53] S. C. Q. Magalhães, M. Taveira, A. R. J. Cabrita, A. J. M. Fonseca, P. Valentão, and P. B. Andrade, "European marketable grain legume seeds: further insight into phenolic compounds profiles," Food Chemistry, vol. 215, pp. 177-184, 2017.

[54] Y. Aguilera, I. Estrella, V. Benitez, R. M. Esteban, and M. A. Martín-Cabrejas, "Bioactive phenolic compounds and functional properties of dehydrated bean flours," Food Research International, vol. 44, no. 3, pp. 774-780, 2011.
[55] R. Amarowicz, I. Estrella, T. Hernández et al., "Free radicalscavenging capacity, antioxidant activity, and phenolic composition of green lentil (Lens culinaris)," Food Chemistry, vol. 121, no. 3, pp. 705-711, 2010.

[56] N. Alshikh, A. C. de Camargo, and F. Shahidi, "Phenolics of selected lentil cultivars: antioxidant activities and inhibition of low-density lipoprotein and DNA damage," Journal of Functional Foods, vol. 18, pp. 1022-1038, 2015.

[57] D. L. Luthria and M. A. Pastor-Corrales, "Phenolic acids content of fifteen dry edible bean (Phaseolus vulgaris L.) varieties," Journal of Food Composition and Analysis, vol. 19, no. 2-3, pp. 205-211, 2006.

[58] Y. Yao, X. Cheng, L. Wang, S. Wang, and G. Ren, "Biological potential of sixteen legumes in China," International Journal of Molecular Sciences, vol. 12, no. 10, pp. 7048-7058, 2011.

[59] A. D’Agostina, G. Boschin, D. Resta, P. Annicchiarico, A. Arnoldi, and J. B. Berger, "Evolution of isoflavones during the growth of plants of Lupinus albus," in "Lupins for Health and Wealth, J. A. Palta and J. B. Berger, Eds., pp. 401-404, Fremantle, Western Australia, 2008.

[60] P. B. Kaufman, J. A. Duke, H. Brielmann, J. Boik, and J. E. Hoyt, "A comparative survey of leguminous plants as sources of the isoflavones, genistein and daidzein: implications for human nutrition and health," The Journal of Alternative and Complementary Medicine, vol. 3, no. 1, pp. 7-12, 1997.

[61] A. López, T. El-Naggar, M. Dueñas et al., "Effect of cooking and germination on phenolic composition and biological properties of dark beans (Phaseolus vulgaris L.)," Food Chemistry, vol. 138, no. 1, pp. 547-555, 2013.

[62] L. Díaz-Batalla, J. M. Widholm, G. C. Fahey, E. CastañoTostado, and O. Paredes-López, "Chemical components with health implications in wild and cultivated Mexican common bean seeds (phaseolus vulgarisL.)," Journal of Agricultural and Food Chemistry, vol. 54, no. 6, pp. 2045-2052, 2006.

[63] F. Giusti, G. Caprioli, M. Ricciutelli, S. Vittori, and G. Sagratini, "Determination of fourteen polyphenols in pulses by high performance liquid chromatography-diode array detection (HPLC-DAD) and correlation study with antioxidant activity and colour," Food Chemistry, vol. 221, pp. 698-697, 2017. 